\title{
The compensatory response of pigs previously fed a diet with an increased fibre content. 1. Growth rate and voluntary feed intake*
}

\author{
G. Skiba ${ }^{1}$, St. Raj, D. Weremko and H. Fandrejewski \\ The Kielanowski Institute of Animal Physiology and Nutrition, \\ Polish Academy of Sciences \\ 05-110 Jabłonna, Poland
}

(Received 15 February 2006; revised version 22 March 2006; accepted 5 July 2006)

\begin{abstract}
The compensatory response of pigs induced by previously feeding a fibre-rich diet was investigated on 54 gilts from 25 to $105 \mathrm{~kg}$ body weight (BW). The experiment consisted of two growth periods: a restriction period imposed by feeding the pigs a HF diet (high-fibre) up to 50 (group HF50) or $80 \mathrm{~kg} \mathrm{BW}$ (group HF80), followed by a realimentation period with diet LF (lowfibre). Pigs of the control groups were continuously fed either diet LF (group LF105) or diet HF (group HF105). During restriction, the HF50 and HF80 animals consumed on average the same amount of feed as the LF animals. In spite of this, their average daily body gain was respectively 111 and $87 \mathrm{~g}$ lower than in the LF animals. During the first stage of realimentation (50 to $80 \mathrm{~kg} \mathrm{BW}$ ) group HF50 animals consumed a greater $(\mathrm{P}<0.01)$ amount of feed daily $(2.80 \mathrm{~kg})$ than animals of the remaining groups (2.56 kg, group LF105; $2.69 \mathrm{~kg}$, group HF80; and $2.68 \mathrm{~kg}$, group HF105). Consequently, the HF50 pigs had the greatest $(\mathrm{P}<0.01)$ daily gain, whereas pigs of groups LF105, HF80 and HF105 grew more slowly (1021 vs 965, 920 and 923 g/day, respectively). During this period, the pigs of groups HF50 and LF105 utilized feed slightly better than those from groups HF80 and HF105. During subsequent realimentation (80-105 kg BW), the performance of pigs did not differ significantly among groups. Our results confirm that the compensatory response lasts a few weeks after changing restriction to realimentation and is more intensive in young than in old pigs. In the case of our study, compensatory growth resulted mainly from a higher voluntary feed intake.
\end{abstract}

KEY WORDS: pig, compensatory growth, dietary fibre, voluntary feed intake

\footnotetext{
* Supported by The European Commission (the V Framework Programme) within Project "Sustainability in the production of pork with improved nutritional and eating quality using strategic feeding in outdoor production". Contract No. QLK5-CT-2000-00162

${ }^{1}$ Corresponding author: e-mail: g.skiba@ifzz.pan.pl
} 


\section{INTRODUCTION}

In out-door production systems, young pigs are fed a concentrate diet semi-ad libitum (or in restricted amounts) and roughage is used to complement such diets. Compared with conventionally fed pigs, such feeding restricts their growth rate and worsens their performance. Much attention is paid, therefore, to finding ways to improve the growth performance of pigs kept in out-door systems. An alternative could be via the phenomenon called compensatory growth, which improves the growth performance of previously restricted animals (de Greef, 1992; Bikker, 1994; Skiba et al., 2001) when they regain free access to conventional, i.e. nonrestricted feed. Recent literature data, however, does not show any studies on the influence of feeding pigs a high fibre diet on the compensatory response. This study assumed that the introduction of the compensatory growth phenomenon in pigs fed in a similar manner as in the out-door system (periodically feeding a high-fibre diet) will improve their performance compared with animals fed both conventionally and similarly to the out-door strategy (continuous feeding of a high-fibre diet).

This study was conducted, therefore, to test the influence of feeding pigs a high-fibre diet up to 50 or $80 \mathrm{~kg} \mathrm{BW}$ on their performance after returning to a conventional diet.

\section{MATERIAL AND METHODS}

Fifty-four crossbreed gilts ( $\partial^{\lambda}$ Duroc $\times q$ Large White) from 25 to $105 \mathrm{~kg} \mathrm{BW}$ were kept individually in $2.6 \mathrm{~m}^{2}$ pens equipped with an automatic feeder and nipple drinker. A central heating and an air-conditioning system in the piggery made it possible to keep the animals under thermo-neutral conditions $\left(16-20^{\circ} \mathrm{C}\right)$. The animals were fed two granulated diets (low-fibre - LF, or high-fibre - HF). The LF diet was based on cereals and soyabean meal, whereas the HF diet was formed by mixing diet LF with $20 \%$ of grass meal. Both diets were supplemented with synthetic amino acids and minerals according to the CVB (1995) system. Characteristics of the diets are presented in Table 1. The grass meal added to the LF diet fulfilled the function of a roughage component, because it was not technically possible to employ the roughage commonly used in out-door production systems. All animals were fed ad libitum: the pigs of treatment LF105 were continuously fed the LF diet, whereas those of treatment HF105, were continuously fed the HF diet. The remaining pigs were fed diet HF up to 50 (treatment HF50) or up to 80 $\mathrm{kg} \mathrm{BW}$ (treatment HF 80), followed by diet LF. Hence, the experiment consisted of two growth periods: restriction imposed by feeding the pigs the HF diet up to 50 
or up to $80 \mathrm{~kg} \mathrm{BW}$, thus realimentation began from 50 or $80 \mathrm{~kg} \mathrm{BW}$, respectively. The pigs fed the HF diet during restriction received less nutrients and energy due to the higher concentration of dietary fibre. Feed intake and growth rates were measured weekly.

Table 1. Ingredient composition, chemical composition and metabolizable energy content of diets used in the experiment

\begin{tabular}{|c|c|c|}
\hline \multirow{2}{*}{ Item } & \multicolumn{2}{|c|}{ Diet } \\
\hline & $\mathrm{LF}$ & $\mathrm{HF}$ \\
\hline \multicolumn{3}{|l|}{ Ingredient, $\mathrm{g} / \mathrm{kg}$} \\
\hline barley & 309 & 247 \\
\hline wheat & 297 & 238 \\
\hline triticale & 90 & 72 \\
\hline maize & 50 & 40 \\
\hline soyabean oilmeal & 180 & 144 \\
\hline rapeseed oilmeal & 50 & 40 \\
\hline dried grass meal & - & 200 \\
\hline premix & 24 & 19 \\
\hline \multicolumn{3}{|l|}{ Chemical composition, $\mathrm{g} / \mathrm{kg} D M$} \\
\hline organic matter & 943.8 & 933.7 \\
\hline crude protein & 211.7 & 190.6 \\
\hline ether extract & 26.6 & 26.6 \\
\hline crude fibre & 42.8 & 85.4 \\
\hline NDF & 59.3 & 57.2 \\
\hline $\mathrm{ADF}$ & 151.0 & 254.0 \\
\hline $\mathrm{N}$-free extractives & 662.7 & 631.1 \\
\hline ash & 56.2 & 66.2 \\
\hline \multicolumn{3}{|c|}{ Nutritive value, $\mathrm{g} / \mathrm{kg} D M$, and energy content } \\
\hline lysine & 11.10 & 9.14 \\
\hline methionine & 3.36 & 2.90 \\
\hline threonine & 6.16 & 5.35 \\
\hline trypthophan & 1.91 & 1.56 \\
\hline metabolizable energy, MJ/kg DM & 14.7 & 12.9 \\
\hline
\end{tabular}

LF-low fibre diet, HF- high fibre diet

The design of the study is presented in Table 2. It was assumed that pigs of treatments LF105 and HF105 were simulating conventional and out-door 
feeding, respectively. Whereas pigs of treatments HF50 and HF80 were simulating animals that were being fed according to the out-door strategy for a certain time only, after which a compensatory growth period was incorporated into their growth pathway.

Table 2. Design of the experiment

\begin{tabular}{lccc}
\hline \multirow{2}{*}{ Group } & \multicolumn{3}{c}{ Feed applied during particular growth period } \\
\cline { 2 - 4 } & $25-50 \mathrm{~kg} \mathrm{BW}$ & $50-80 \mathrm{~kg} \mathrm{BW}$ & $80-105 \mathrm{~kg} \mathrm{BW}$ \\
\hline LF105 & $\mathrm{LF}(\mathrm{n}=18)$ & $\mathrm{LF}(\mathrm{n}=12)$ & $\mathrm{LF}(\mathrm{n}=6)$ \\
HF50 & $\mathrm{HF}(\mathrm{n}=14)$ & $\mathrm{LF}(\mathrm{n}=12)$ & $\mathrm{LF}(\mathrm{n}=6)$ \\
HF80 & $\mathrm{HF}(\mathrm{n}=11)$ & $\mathrm{HF}(\mathrm{n}=9)$ & $\mathrm{LF}(\mathrm{n}=6)$ \\
HF105 & $\mathrm{HF}(\mathrm{n}=11)$ & $\mathrm{HF}(\mathrm{n}=9)$ & $\mathrm{HF}(\mathrm{n}=6)$ \\
\hline
\end{tabular}

LF-low fibre diet, HF- high fibre diet, LF105- group of pigs fed the LF diet throughout the study, HF50- group of pigs fed the diet HF up to $50 \mathrm{~kg} \mathrm{BW}$ following the diet LF, HF80- group of pigs fed the diet HF up to $80 \mathrm{~kg} \mathrm{BW}$ following the diet LF, HF105- group of pigs fed the diet HF throughout the experiment

The experiment was a part of a serial slaughter study, therefore, as it proceeded, pigs were slaughtered at 50,80 and $105 \mathrm{~kg} \mathrm{BW}$ to determine their chemical body composition and composition of daily gain (detailed numbers of slaughtered animals and body composition are given in the second part of this study, Skiba et al., 2006). As a result, the number of animals in a particular growth period decreased (Table 2 ) and only 24 pigs were in the experiment from the beginning until the end.

Statistical analysis was performed by ANOVA analysis of variance using Statgraphics Centurion version 15.0 Plus software.

\section{RESULTS}

\section{Restriction period}

All pigs completed the restriction period. The pigs of groups HF50, HF80 and HF105 were treated the same when grown from 25 to $50 \mathrm{~kg} \mathrm{BW}$, as were those in groups HF80 and HF105, when grown from 25-80 kg BW. Therefore, the results for these groups are discussed together (values given in the text represent average values for the mentioned groups) and compared with group LF105. Average daily feed intake (FI) did not differ between groups of pigs regardless of the duration of the restriction (Table 3). Nutrient intake did, 
Table 3. Average daily intake of feed (FI), metabolizable energy (ME), digestible protein (DP), and daily body gain (ADG), days taken and feed conversion ratio (FCR) during the restriction period

\begin{tabular}{|c|c|c|c|c|c|c|c|c|}
\hline $\begin{array}{l}\text { Duration of the } \\
\text { restriction }\end{array}$ & Group & $\mathrm{n}$ & $\begin{array}{l}\text { FI } \\
\mathrm{kg}\end{array}$ & $\begin{array}{l}\text { ME } \\
\text { MJ }\end{array}$ & $\begin{array}{c}\mathrm{DP} \\
\mathrm{g}\end{array}$ & $\begin{array}{c}\mathrm{ADG} \\
\mathrm{g}\end{array}$ & Days & $\begin{array}{c}\text { FCR } \\
\mathrm{kg} / \mathrm{kg}\end{array}$ \\
\hline \multirow{6}{*}{$25-50 \mathrm{~kg}$} & LF105 & 18 & 1.91 & 25.0 & 292 & 889 & 28 & 2.16 \\
\hline & HF50 & 14 & 1.94 & 22.4 & 248 & 801 & 31 & 2.43 \\
\hline & HF80 & 11 & 1.87 & 21.8 & 240 & 783 & 32 & 2.41 \\
\hline & HF105 & 11 & 1.93 & 22.4 & 247 & 762 & 32 & 2.55 \\
\hline & & SEM & 0.02 & 0.33 & 3.32 & 15.2 & 0.46 & 0.05 \\
\hline & & $\mathrm{P}$ & NS & $* *$ & $* * *$ & $* * *$ & $* * *$ & $* * *$ \\
\hline \multirow{5}{*}{$25-80 \mathrm{~kg}$} & LF105 & 12 & 2.25 & 29.5 & 345 & 919 & 60 & 2.45 \\
\hline & HF80 & 9 & 2.26 & 26.2 & 289 & 813 & 67 & 2.78 \\
\hline & HF105 & 9 & 2.31 & 26.8 & 296 & 843 & 65 & 2.74 \\
\hline & & SEM & 0.03 & 0.46 & 4.58 & 24.6 & 1.15 & 0.05 \\
\hline & & $\mathrm{P}$ & NS & $* * *$ & $* *$ & $* * *$ & $* * *$ & $* * *$ \\
\hline
\end{tabular}

$* * * \mathrm{P}<0.001 ; * * \mathrm{P}<0.01 ; \mathrm{NS}-$ non significant

however, differ between treatments, as both groups of pigs fed diet HF to 50 and 80 kg BW consumed on average $15 \%(\mathrm{P}<0.01)$ less digestible protein (DP) and 2.85 MJ less $(\mathrm{P}<0.01)$ metabolizable energy $(\mathrm{ME})$ than those in group LF105. Moreover, the average daily gain (ADG) of pigs fed the HF diet to 50 and $80 \mathrm{~kg}$ BW was lower $(\mathrm{P}<0.001)$ by 110 and $87 \mathrm{~g} /$ day, respectively. Consequently, these pigs took 4 and 6 days more $(\mathrm{P}<0.001)$ to reach 50 and $80 \mathrm{~kg} \mathrm{BW}$, respectively, and the feed conversion ratio (FCR) was worse as they needed 0.32 and $0.29 \mathrm{~kg}$ more $(\mathrm{P}<0.001)$ feed per kg body gain, respectively, than the pigs in group LF105.

\section{Realimentation period}

During growth from 50 to $80 \mathrm{~kg} \mathrm{BW}$ the pigs from group HF50 consumed the greatest amount of feed daily compared with HF80, HF105 and LF105 animals ( 2.80 vs $2.69,2.68$ and $2.56 \mathrm{~kg}$, respectively; $\mathrm{P}<0.01)$. The ADG of animals differed $(\mathrm{P}<0.05)$ between treatments (Table 4$)$ and took the following order: $1021 \mathrm{~g}$ (group HF50), $965 \mathrm{~g}$ (group LF105), $923 \mathrm{~g}$ (group HF105) and 920 g (group HF80). Consequently, the animals needed 30, 32, 33 and 33 days, respectively, (NS difference) to reach $80 \mathrm{~kg} \mathrm{BW}$. Pigs in group HF50 consumed the greatest amount $(\mathrm{P}<0.001)$ of $\mathrm{ME}$, and $\mathrm{DP}$ as compared with the pigs from groups LF105, HF80 and HF105 (36.7, 429 vs 33.5, 392; 31.0, 345 and 31.1 MJ, $343 \mathrm{~g}$, respectively). Differences in FCR were not significant, although the pigs of groups LF 105 and HF50 needed less feed per kg body gain than pigs of groups HF80 and HF105. 
Table 4. Average daily intake of feed (FI), metabolizble energy (ME), digestible protein (DP), and daily body gain (ADG), days taken and feed conversion ratio (FCR) during a particular realimentation period

\begin{tabular}{llccccccc}
\hline $\begin{array}{l}\text { Duration of the } \\
\text { realimentation }\end{array}$ & Group & $\mathrm{n}$ & $\begin{array}{c}\text { FI } \\
\mathrm{kg}\end{array}$ & $\begin{array}{c}\text { ME, } \\
\text { MJ }\end{array}$ & $\begin{array}{c}\text { DP } \\
\mathrm{g}\end{array}$ & $\begin{array}{c}\text { ADG } \\
\mathrm{g}\end{array}$ & Days & $\begin{array}{c}\mathrm{FCR} \\
\mathrm{kg} / \mathrm{kg}\end{array}$ \\
\hline & LF105 & 12 & 2.56 & 33.5 & 392 & 965 & 32 & 2.65 \\
& HF50 & 12 & 2.80 & 36.7 & 429 & 1021 & 30 & 2.74 \\
$50-80 \mathrm{~kg} \mathrm{BW}$ & HF80 & 9 & 2.69 & 31.0 & 345 & 920 & 33 & 2.89 \\
& HF105 & 9 & 2.68 & 31.2 & 343 & 923 & 33 & 2.90 \\
& SEM & & 0.05 & 0.71 & 7.52 & 28.1 & 0.92 & 0.09 \\
& P & & $* *$ & $* * *$ & $* * *$ & $*$ & NS & NS \\
& LF105 & 6 & 3.10 & 40.6 & 475 & 1002 & 25 & 3.10 \\
& HF50 & 6 & 3.27 & 42.8 & 501 & 945 & 25 & 3.47 \\
& HF80 & 6 & 3.10 & 40.6 & 475 & 948 & 26 & 3.27 \\
$80-105 \mathrm{~kg} \mathrm{BW}$ & HF105 & 6 & 3.38 & 39.2 & 433 & 938 & 26 & 3.60 \\
& SEM & & 0.11 & 1.29 & 14.3 & 61.5 & 1.43 & 0.20 \\
& P & & NS & NS & NS & NS & NS & NS \\
\hline
\end{tabular}

*** $\mathrm{P}<0.001 ; * * \mathrm{P}<0.01 ; * \mathrm{P}<0.05$; NS - non significant

Moreover, performance data during the following period of realimentation (80 to 105 $\mathrm{kg} \mathrm{BW}$ ) did not differ between groups of animals, although pigs from group LF105 grew slightly faster, and utilized feed slightly better, than the pigs of the remaining groups.

\section{Overall growth period}

Pigs in groups HF50 and HF105 consumed daily more $(\mathrm{P}<0.05)$ feed as compared with the LF105 and HF80 pigs (2.70 and $2.63 \mathrm{~kg}$ vs 2.50 and $2.48 \mathrm{~kg}$, respectively; Table 5). The pigs in groups HF50 and LF105 did show, however,

Table 5. Average daily intake of feed (FI), metabolizble energy (ME), digestible protein (DP) and average daily gain (ADG), days taken and feed conversion ratio during the whole growth period

\begin{tabular}{lccccccc}
\hline Group & $\mathrm{n}$ & $\begin{array}{c}\mathrm{FI} \\
\mathrm{kg}\end{array}$ & $\begin{array}{c}\text { ME } \\
\mathrm{MJ}\end{array}$ & $\begin{array}{c}\mathrm{DP} \\
\mathrm{g}\end{array}$ & $\begin{array}{c}\text { ADG } \\
\mathrm{g}\end{array}$ & Days & $\begin{array}{c}\mathrm{FCR} \\
\mathrm{kg} / \mathrm{kg}\end{array}$ \\
\hline LF105 & 6 & 2.50 & 32.7 & 383 & 943 & 86 & 2.65 \\
HF50 & 6 & 2.70 & 34.3 & 395 & 938 & 86 & 2.89 \\
HF80 & 6 & 2.48 & 30.1 & 339 & 846 & 92 & 2.94 \\
HF105 & 6 & 2.63 & 30.5 & 337 & 894 & 91 & 2.95 \\
SEM & & 0.07 & 1.52 & 9.46 & 30.0 & 2.53 & 0.08 \\
P value & & $*$ & $* *$ & $* *$ & $*$ & $*$ & $*$ \\
\hline
\end{tabular}

** $\mathrm{P}<0.01 ; * \mathrm{P}<0.05$

the greatest $(\mathrm{P}<0.01)$ daily intake of $\mathrm{ME}$ (34.3 and $32.7 \mathrm{MJ})$, whereas consumption of ME by the pigs of groups HF80 and HF105 was lower (30.1 and 30.5 MJ, respectively). Daily consumption of DP by animals of groups HF50 and LF105 was similar (on average $389 \mathrm{~g}$ ) and higher $(\mathrm{P}<0.01)$ than that of the HF80 and HF105 pigs (on average $338 \mathrm{~g}$ ). ADG of the HF50 and LF105 animals was similar 
and higher $(\mathrm{P}<0.05)$ compared with pigs of groups HF80 and HF105 (938 and 943 vs 846 and $894 \mathrm{~g}$, respectively). The duration of the experiment differed $(\mathrm{P}<0.01)$ between treatments and amounted to: 86 days (groups HF50 and LF105), 91 (group HF105) and 92 days (group HF80). FCR of the HF50, HF80 and HF105 pigs was, however, similar (on average $2.93 \mathrm{~kg} / \mathrm{kg}$ ) and worse $(\mathrm{P}<0.05)$ than in the pigs of group LF105 $(2.65 \mathrm{~kg} / \mathrm{kg})$.

\section{DISCUSSION}

The average daily feed intake (expressed in fresh weight) of restricted pigs was similar to that in the control group. If, however, feed consumption was considered during the following growth period, it was found that pigs fed diet HF consumed a similar amount of feed as those fed diet LF only when they grew from 25 to $50 \mathrm{~kg} \mathrm{BW}$ (Figure 1). During the following growth period from 50 to $80 \mathrm{~kg} \mathrm{BW}$, however, pigs fed the HF diet consumed almost 5\% more feed, and during growth from 80 to $105 \mathrm{~kg}$, this difference increased to $9 \%$. Growth from 25 to $50 \mathrm{~kg} \mathrm{BW}$ of the pigs fed the HF diet lasted almost 5 weeks, and it seems that this time was sufficient for the animals to adapt their gastrointestinal tract to consume and digest a greater amount of feed with an increased fibre content. A

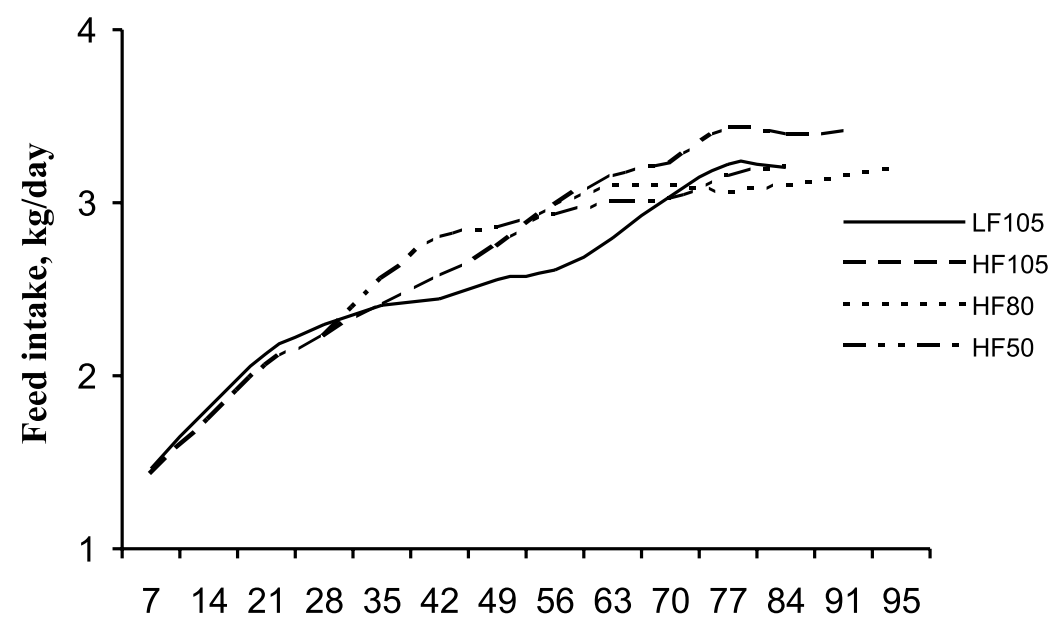

Days of the experiment

Figure 1. Voluntary feed intake of pigs during particular days of the study. To make a figure more clearly a daily feed intake till 28 days of the study (for the group HF50, HF80 and HF105) and till 56 days of the study (for the group HF80 and HF105) is expressed as an average value 
result of this unexpected response was the severity of the restriction lessening as its duration increased. Consequently, the difference in the growth rate between pigs fed diet HF and those fed diet LF decreased (from -14\% during growth up to $50 \mathrm{~kg} \mathrm{BW}$ to approximately $-6 \%$ during the following growth period). Such a response was quite different from the work that has been reported so far, when pigs were underfed protein only (e.g., Kyriazakis et al., 1991; Skiba et al., 2001). This was due to the increased size and, probably, capacity of GI tract organs (stomach, small and large intestine), whose sizes are positively influenced by both high fibre content and duration of such feeding (Jørgensen et al., 1996; Wenk, 2001).

The results of our study show that the voluntary feed intake of pigs that were compensated from $50 \mathrm{~kg} \mathrm{BW}$ onwards was $9 \%$ higher than of pigs continuously fed the low fibre diet (LF), and by over $6 \%$ higher that those continuously fed the high-fibre $\operatorname{diet}(\mathrm{HF})$ when grown to $80 \mathrm{~kg}$ BW. During the following period of realimentation this difference decreased to $5 \%$ but, compared with pigs continuously fed the HF diet, it was $3 \%$ lower. Comparison of the voluntary feed intake of compensating pigs in our study with that of pigs previously restricted with protein or feed/energy intake, it is clear that they responded rather similarly to the latter (Owen et al., 1971; Bikker, 1994; Skiba et al., 2001), as animals on which compensatory growth was induced by previous protein restriction do not consume more feed (de Greef, 1992; Skiba et al., 2001).

In fact, the greater feed intake of pigs compensating from $50 \mathrm{~kg} \mathrm{BW}$ was only periodical, but resulted in a significantly faster growth rate during this

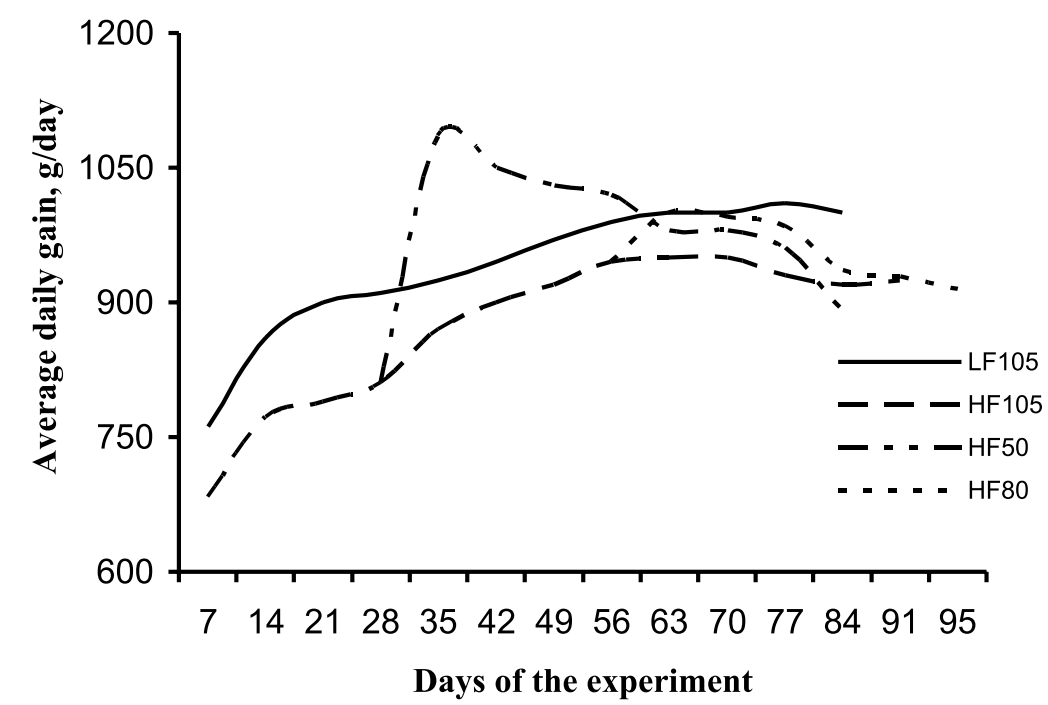

Figure 2. Average daily gain of pigs during particular days of the experiment. To make a figure more clearly a daily gain till 28 days of the study (for the group HF50, HF80 and HF105) and till 56 days of the study (for the group HF80 and HF105) is expressed as an average value 
time. During the following period, however, the growth rate decreased and was similar to that of pigs continuously fed a LF diet, as well as to that of pigs compensated from $80 \mathrm{~kg} \mathrm{BW} \mathrm{(group} \mathrm{HF80).} \mathrm{Observation} \mathrm{of} \mathrm{the} \mathrm{growth} \mathrm{rate} \mathrm{during}$ particular weeks of the study (Figure 2) confirmed that compensatory growth is shown mainly during the first few weeks after the change from restriction to realimentation (Skiba et al., 2001) and that its intensity is greater in younger than in older animals. On the other hand, increasing the duration of the restriction period as well as its intensity is positively correlated with the subsequent compensatory growth (de Greef, 1992). Nevertheless, the response of pigs restricted for a long time is surprising. One of the reasons could be the atypical response of these pigs to prolonged restriction mentioned at the beginning of this discussion. Despite the temporary compensatory response of the pigs from $50 \mathrm{~kg} \mathrm{BW}$, its intensity was so strong that they could fully make up for the age difference developed during restriction.

Our results allow us to assume that a reason for the faster growth rate of compensating pigs was the enhanced feed/energy intake of pigs, but only those that compensated from $50 \mathrm{~kg} \mathrm{BW}$. The greater appetite of these pigs allowed them to ingest more nutrients and direct them to cover their growth needs. That it was the higher voluntary feed intake that played the most important role in the compensatory response of our pigs is supported by the finding that the feed conversion ratio (FCR) of the compensating animals was practically similar to the values in pigs continuously fed diet LF, but better than in pigs continuously fed the HF diet. This contradicts the results given by Oksbjerg et al. (2002), who found that the reason for faster compensatory growth was improved FCR. Thus, our data indicate that better feed utilization did not always play a crucial role in compensatory growth and that a change in appetite of the realimented pigs could also participate in the compensatory response.

\section{CONCLUSIONS}

Feeding pigs a diet with an increased fibre content (by supplementing a roughage component to the basal diet) without previous adaptation to this kind of feeding resulted in deterioration of their performance. If such feeding is prolonged, however, or if the animals are previously adapted to consume a diet with an increased fibre content, they can compensate the intake of nutrients and enhance their growth rate to some extent. Thus, they do not exactly behave as underfed animals. The severity of the restriction of animals that have undergone such treatment is, therefore, less than expected. Moreover, besides other factors, greater voluntary feed intake could also contribute to the compensatory response. 
Our results show that incorporating the phenomenon of compensatory growth into out-door production has a positive effect (however, only for a certain period) on pig performance. Nevertheless, in terms of overall growth performance, compensating pigs were similar to those fed in a manner resembling conventional feeding and insignificantly better than those fed similarly to the out-door method, but only those pigs previously restricted to a smaller body weight.

\section{REFERENCES}

Bikker P., 1994. Protein and lipid accretion of body components of growing pigs: effects of body weight and nutrient intake. PhD. Thesis, Wageningen University (The Netherlands), pp. 1-203

CVB, 1995. Tables of Feedstuffs. Information about Composition, Digestibility and Feeding Value (in Dutch), No. 18. Central Veevoeder Bureau, Lelystad (The Netherlands)

De Greef K.H., 1992. Prediction and production: Nutrition induced tissue partitioning in growing pigs. PhD. Thesis, Wageningen University (The Netherlands), pp. 1-117

Jørgensen H., Xin-Quan Z., Eggum B.O., 1996. The influence of dietary fibre and environmental temperature on the development of the gastrointestinal tract, digestibility, degree of fermentation in the hind-gut and energy metabolism in pigs. Brit. J. Nutr. 75, 365-378

Kyriazakis L., Stamataris C., Emmans G.C., Whittemore C.T., 1991. The effects of food protein content on the performance of pigs previously given foods with low or moderate protein content. Anim. Prod. 52, 165-174

Oksbjerg N., Sørensen M.T., Vestergaard M., 2002. Compensatory growth and its effect on muscularity and technological meat quality in growing pigs. Acta Agr. Scand., Sect. A, Anim. Sci. 52, 85-90

Owen J.B., Ridgman W.J., Wyllie D., 1971. The effect of food restriction on subsequent voluntary feed intake of pigs. Anim. Prod. 13, 537-546

Skiba G., Fandrejewski H., Raj S., Weremko D., 2001. The performance and body composition of growing pigs during protein or energy deficiency and subsequent realimentation. J. Anim. Feed Sci. 10, 633-647

Skiba G., Raj S., Weremko D., Fandrejewski H., 2006. Compensatory response of pigs previously fed a diet with increased fibre content. 2. Chemical body components and composition of daily gain. J. Anim. Feed Sci. 15, 403-415

Wenk C., 2001. The role of dietary fibre in the digestive physiology of the pig. Anim. Feed Sci. Tech. 90, 21-33 